Н. О. Данилюк

\title{
СЛОВ'ЯНСЬКІ ЗАПОЗИЧЕННЯ В УКРАЇНСЬКИХ НАРОДНОПІСЕННИХ ТЕКСТАХ
}

Данилюк Н. О. Слов'янські запозичення в українських народнопісенних текстах.

У статті розглянуто запозичення зі старослов'янської, польської, чеської, російської та білоруської мов у текстах українських народних пісень. Вказано на тематичні групи запозиченої лексики.

Ключові слова: запозичення, народнопісенний текст, тематична група, лексика.

Данилюк Н. А. Славянские заимствования в украинских народно-песенных текстах.

В статье рассмотрено заимствования из старославянского, польского, чешского, русского и беларусского языков в текстах украинских народных песен. Указано на темматические группы заимствованной лексики.

Ключові слова: заимствование, народно-песенный текст, темматическая группа, лексика.

Danylyuk N. A. Slavic Borrowings in the Ukrainian Folk Songs Texts.

The article deals with the study of the Slavic borrowings of in the Ukrainian folk songs texts. The thematic groups of the borrowing lexics are indicated.

Key words: borrowing, folk songs text, thematic group, lexics.

Як відомо, історію розвитку словникового складу української мови у XX ст. досліджували Л. А. Булаховський [3], А. А. Бурячок [4], В. М. Русанівський [12] та інші вчені. Вони відзначали, що «поява нових слів і розвиток нових значень старих слів здебільшого безпосередньо пов'язані із розвитком матеріальної і духовної культури, 3 розвитком людського мислення» [7 c. 5]. У працях славістів XIX ст. Й. М. Бодянського [2], 
О. М. Афанасьєва [1], Ф. І. Буслаєва [5], О. М. Веселовського [6], О. О. Потебні [11] також було здійснено спробу простежити особливості лексики народної поезії з погляду ії походження, подати етимологічні довідки слів-символів та міфологем.

Однак потрібно визнати, що спеціальних студій про іншомовні запозичення в українських пісенних текстах обмаль. Зокрема, назвемо статті Г. М. Халимоненка [15], В. Г. Скляренка [13; 14], Л. П. Павленко [9; 10] Н. М. Сологуб [15], у яких приділено увагу походженню уснопоетичної лексики. У російській лінгвістиці Р. М. Козлова захистила дисертацію, спеціально присвячену запозиченням у мові народних пісень [8].

Дослідники народної поезії зауважують, що споконвічна лексика в текстах усної поезії (так само, як і в українській літературній мові XIX ст. загалом) становить до 95\%, а запозичена - менше 5\%. До народних пісень у різні часи ввійшли іншомовні запозичення зі слов'янських (старослов'янської, польської, чеської, російської, білоруської та ін.) і неслов'янських (грецької, латинської, німецької, французької, італійської, іспанської, англійської, тюркських та ін.) мов.

Найдавніші одиниці, які прийшли зі слов'янських мов, - це старослов'янізми. Вони почали поширюватися 3 кінця Х ст., коли старослов'янська мова, яка виникла в IX ст. на основі македонського діалекту староболгарської мови, стала виконувати функції церковної, «священної» мови. Поступово перетворившись на мову освіти, культури $\mathrm{i}$ науки, ця мова збагачувала своїми лексичними надбаннями інші слов'янські мови. Книжні за стилістичним забарвленням слова проникали й до народнорозмовного та народнопісенного мовлення українців.

Зауважимо, що в текстах українських народних пісень власне лексичних старослов'янізмів порівняно небагато (жена (жона), жемчуг, мисль, утроба, любезная, уповати (вповати) та ін.): Якби я добра жена, То сиділа б я дома [ВП, с. 367]; Ой подумай ти, мисле, об мойм нещасті [МГ, с. 55]; Бо ти дівчина любезная [ЛУ, с. 22]; Не вповала на худобу, а на його вроду [AМ, с. 83]; Да приймися, бабусенько, за мою утробу [MВ, с. 167].

Старослов'янізми передусім виділяють за фонетико-словотвірними ознаками. Цим словам властиві такі фонетичні ознаки: 1) неповноголосні звукосполучення $p a$, ла відповідно до східнослов'янських оро, оло, напр.: Наӥхали боярочки з граду [IM, с. 65]; Ой сохрани, боже [MB, с. 173]; $А$ я $з$ тоски та печалі піду, млада, в темний ліс [МГ, с. 45]; 2) сполучення приголосних жд (рожденний, нарожљенную): Другу душечку нарожденную [MB, с. 166]; Христу рожденному всі изарі грают [ВШ, с. 37]. Старослов'янізми мають такі морфолого-словотвірні показники: 1) префікси воз- (вос-) (вознести, воздвигати, воскресіння та ін.): Возрадуються люди старі і діти малі [IM, с. 57]; I сама возлюбиш мня [МГ, с. 43]; пре(преславний, прегарний, прехороший, пречиста, престол): Ти, дівчино, ти прекрасна, як на небі зоря ясна [БГ, 3, с. 241]; Пречиста діва сина вродила 
[ВШ, с. 34]; Та поставлене на столи, На столи, на престоли (гіллячко. Н. Д.) [IM, с. 79]; 2) іменникові суфікси -тель (повелитель), -знь (приязнь), -ств(о) (братство), -тв(а) (битва, молитва); -ость (печалость, жалость, молодость, нелюбость, печалость): Ой не находь, Литва, буде з вами битва [AМ, с. 215]; Батеньку на жалості, Сестрицям - на печалості [IM, с. 72]; -ощ(i) (любощъі, милощуі, заздрощзі): Про любощі спом'янули, Що любощі, щзо милощці [MB, с. 231]; 3) дієприкметникові суфікси -ащз (-ящ)), -ущз (роботящций, сущзиц̆); 4) закінчення іменників -ію: То не будеш своєю смертію умирати [МГ, с. 83]; 5) складні слова 3 першою частиною благо-, добро-, довго-, перво-, щзиро- (благовірний, благодать, добродій, первовічний, щзирозлатний): Хвалим тя, господи, і благодарим [33, с. 134]; Та й раду радять первовічную, Первовічную, довговічную [КОП, с. 395]; Другому рибалки - чирозлатний перстень (щирозлотний - Н. Д.) [MВ, с. 128]; 6) дієслово-зв'язка єсть, напр.: Скажи ж ти нам, дяченьку, Що то єсть один? [ДЯ, с. 78].

Старослов'янізми сприяють створенню урочистого, високого мовлення. Їх поява в піснях спричинена, очевидно, доброю обізнаністю носіїв фольклору 3 церковнослов'янською мовою. У деяких текстах знаходимо цитовані вислови 3 відомих молитов, які вжито в пізніше створених текстах, напр.: Ой видить Бог, видить Творець, Що ввесь мир погибає, Архангела Гавриїла В Назарет посилає [ГВ, с. 121]; Боже Великий, єдиний, Наму Вкраӥну храни. Волі і світла промінням Ти ї̈ осіни [M, с. 90]. Інколи одиниці, взяті з християнських молитов, поєднано iз ситуативно-побутовим мовленням, як-от: Святий Боже, святий кріпкий, Ще й святий безсмертний, Заболіла головонька, Мабуть треба вмерти [ДЯ, с. 385]; Ой сохрани, Божсе, борони, Боже, щз я сказала, ізговорила! Щоб мого милого пречиста покрила [MB, с. 173]; А мені посагу твого не треба, Наградить нам господь з високого неба [MB, с. 221]. Уживання книжної старослов'янської та розмовно-зниженої лексики в тих же мікроконтекстах може призвести до виникнення жартівливого забарвлення, приміром: Уповала ж я на брови, як баран на роги [МГ, с. 43].

Запозичення з польської мови (полонізми) належать до найдавніших. Їх зумовили, насамперед, тривалі контакти українців та поляків у давньоруський період та середні віки. Полонізми - це назви: 1) осіб за віковою ознакою, посадою чи соціальним статусом (війт, возний, жовнір, міщзанин, сотник, хлопец̧ь та ін.): Клічуц̧ь вуйта до двора, Із сотніком обадва [ФК, с. 277]; Пан возний позов дасть [СБГ, 1, с. 248]; Пімов милий у жсовніри, а я їуу в черниченьки [ПЧ, 5, с. 54]; Не пішла б я за селянина, а пішла б я за міманина [ПЧ, 3, с. 472]; Хлопці-риболовці, удалі молодиі, ви закиньте сітку через синє море [ПЧ, 5, с. 28]; 2) людей за певними рисами поведінки, характеру (баламут та ін.): Баламуте всього світа, баламутим мої літа [СБГ, 1, с. 24] (первинно баламуm - 'Порушник спокою'); 3) споруд і предметів побуту ((д)зигарок, збруя, кост(u)ьол, крамниия та 
ін.): Там я буду за невістку, де в хаті дзигарок [ПК, с. 339]; Постав коня у станочку, повісь збрую на кілочку [MМ, 64]; А в косцьолі свічи горять [Л]; Завів мене у крамницю, Купив добрую сподницюю [Н]; 4) предметів одягу, взуття (кошуля (кошулька), сукня (сукєнка), боти та ін.): Шила кошульку 3 тонкого рубку [MB, с. 151]; Їхала дівка через бір, а на їй сукня в дев 'ять піл [СБГ, 4, с. 227]; Та на козаку боти, та на козаку нові та німецької роботи [БГ, 3, с. 286]; 5) станів людини (х(в)ороба): Ніякою хоробою не будеш хорувати [БГ, 2, с. 32]; 6) ознак (кепський, ладний, необачний, прикрий та ін.): Лучче з добрим загубити, як з кепським найти (прислів’я); Лужко ж моє ладне, мальоване [ПЧ, 5, с. 12]; Попереду Сагайдачний, щзо проміняв жінку на тютюн $і$ люльку, необачний [Л]; Червоний, аж прикрий (Н); 7) дій (зичити, сподівати(ся)): Нехай не плачуть, щзо нам зле зичуть [СБГ, 2, с. 157]; До себе великого лицаря Семена Палія у гості сподіває [ММ, с. 89]; 8) ознак дій (бар(д)зо, ладно): Ой ви, Ясси, мої Ясси! Були колись барзо красні [MК, с. 141]; Ой дай на мене коня ладненько [IM, с. 84] та ін.

Назви осіб, узяті з польської мови, розглядає в окремій статті Л. П. Павленко [9], вказуючи на їхній зв’язок із історією та соціальнополітичною ситуацією в Україні.

Власні імена теж зазнають іншомовних впливів, як-от: Йван / Ясонько / Явсенько; Катерина / Касюля, Маньочка / Манюля, Ганя / Гандзюля і под.: Продай, Ясьоньку, коники до роботи; На посад, Манюлю, на посад; Явсенько виїжджає, Напротів його Гандзюля його послания посилає [СП, сс. 45, 87, 189]. Особливо багато подібних одиниць у піснях, зафіксованих на українсько-польському порубіжжі.

Зазначимо, що через польську мову приходили в українську мову латинські й німецькі запозичення, напр.: гетьман - пол. hetman - 3 нім. Hauptmann; крам - пол. kram - 3 нім. Kram і похідне крамар [CIC, с. 191, c. 459]. Вони теж потрапляють до текстів народних пісень, як-от: Eй, чи гаразд, чи добре наш пан гетьман Хмельниџький починив, щзо з ляхами із мостивими панами у Білій Церкві замирив [СБГ, 1, с. 281]; А побігла Бондарівна Поміжс крамарями [IM, с. 192].

До української мови 3 найдавніших часів увійшло чимало чеських слів, які потім також використано в народних піснях. Серед них назвемо такі: брама, ганьба, замок, смутний, табір, чекати й інші, напр.: А в нашім двору гірше, як в неволі, вийди за браму, наплачся доволі [ПЧ. 5, 344]; Я парубку ганьби не дам [MB, с. 125]; А на щзо ж ти мене покидаєш у мурованім замку? [АМ, с. 14]; Хазяїн смутний, все здихає [СБГ, 4, с. 160]; Там татари табором стали [ЯГ, 4, с. 403]; Два третього не чекають [СБГ, 4, с. 449].

Завдяки російській мові, вплив якої особливо помітний із другої половини ХУІІ ст., запозичено багато книжної та розмовної лексики. У іiі складі виділимо такі часто вживані групи назв: 1) осіб за віковим і 
соціальним статусом та родом занять (парень, дєвушка, мужик, работнік, родите(и)лі, государ, барин(я), батюшка, ісправник, поручик, прапорщик, вор та ін.): Любив парень молоду дівчину Да не довго [MВ, с. 341]; Помагайбі, батюшка, мой батюшка [МГ, с. 127]; Ой ти, барін, ти дурак [ФК, с. 248]; 2) предметів побуту, знарядь праці, напоїв, страв (кроватка, топор, сапог, булка, водка, чай): На тій кроватці Дівочки спали [MВ, с. 103]; Будем чаєм ноповать, Ще й булками годовать [33, с. 371]; 3) зброї та військової атрибутики (руж' $\epsilon$, флаг): Ой ішли козаченьки із-за Дону, Та несли ружс'є, шаблю за собою [MB, с. 311]; 4) часових проміжків (февраль, март, май, минутка): Й у місяиі февралі панщзина пропала [33, с. 337]; 4) грошових одиниць (рубель, дєньгі): Що у нас на Дону не тчуть, не прядуть ... Все з дєнєе живуть [МГ, с. 77]; 5) економічно-господарських понять (податок, сахарний завод): А мій милий у заході, У сахарному заводі [IM, с. 278]; 6) назв частин голови (глаза): Чорною китайкою да й глаза накрито [ФК, с. 280]; 7) абстрактних понять (чепуха, вракі): розказати вам чепуху, ілі просто вракі [ФК, с. 275]; 8) ознак дій (больно, сейчас): Хоч плєчушки болять больно, Та девушек любить вольно [IM, с. 237] та ін. У словах із російськими формотвірними афіксами найпродуктивнішими є префікс роз(розудалий, розлюбезний, роздіваться) та суфікс -ушк- (-юшк-) (кумуика, голубушка, удовушка, дєвушка, батюшка, матушка, дубровушка, реб 'ятушки, плєчушки, Мар 'юшка та ін.): Не журися, моя розлюбезна [IM, с. 125]; Журилася молода удовушка, Що ни скошана зелена дубровушка [ПД, 3, с. 384]; А як прийде батюшка, викупить мене... А як прийде матушка, викупить мене [MB, с. 259]. Через російську до української мови потрапляли французькі та німецькі назви із військової сфери (гусар, генерал, драгун, майор, улан) тощо, які подекуди виявляємо і в піснях, напр.: Виступають молоді гусари; По крилечкам пани-генерали [IM, с. 231]; Чому рано не була? - Боялася драгуна [ПЧ, 3, с. 102]; У майора на дворі стоять столи тесові [IM, с. 261]; А в улана добре жити, довбешкою воші бити [СБГ, 4, с. 333]. Вживаючись в усталених пісенних формулах, вони зберігають забарвлення новизни, небуденності.

У текстах, записаних на території українсько-білоруського пограниччя, виявляємо фонетичні та лексичні білорусизми, серед яких назви: 1) людей (молодозьон - 'кавалер', народзєи - 'люди'): Бувай здоров, вєсь народзєц! А сєм молодозьоноу женітса [ФК, с. 267, с. 278]; 2) предметів побуту (булавкі - 'кайдани', кручьє - 'крюки на відро в колодязі', селєдушка - 'можливо, прикраса'): Ведуть мєнє в булавкі; Глубокіє коладзезі, залєзниє кручьє [ФК, с. 207, с. 205]; 3) рослин (краскі 'квіти'): Ой шо ж гето за краскі ? [ФК, с. 224]; 4) тварин і птахів: Зьовзюля кує - не чує [ФК, с. 218]; 5) географічних об'єктів (мурлач 'луг'): Зєльоний луже, мурлачу! [ФК, с. 267]; 6) ознак (щари-бури - 'сірийбурий'): Котки два, Шари-бури обидва [СП, с. 69]; 7) дій (подгорбісь 'причепурися', зікає - 'свариться', нє ходзі - 'не ходи': А на ичєбє, нєвєхна, 
сьвокор зікає [ФК, с. 207]; 8) відношень: докуль - 'поки' А тепер не забуду, Докуль же жити буду [СП, с. 47].

Зауважимо, що одиниці, взяті з різних мов на порубіжних територіях, нерідко набувають стилістичного забарвлення. Приміром, досліджуючи польські народнопісенні тексти із Люблінщини, Є. Бартмінський указав на використання українізмів зі стилістичною метою. На думку вченого, вони «слугують ритмо- і римотворчим засобом, підкреслюють важливість даної конструкції, створюють настроєвість, розмежовують певні форми, сигналізують про емоційний тон розповіді» [17, с. 273]. Автор називає українськими «поетизмами» словоформи stajennica, pierścieniec, mateńka, poleńko, molody, szyty, spaty, posadzity, wstaty та ін.

Отже, українська мова 3 найдавніших часів послуговувалася лексичними запозиченнями зі слов'янських мов - старослов'янської, польської, чеської, російської, білоруської та інших, які згодом потрапляли й до народнопісенних текстів. Більшість цих одиниць носіями фольклору сприймалася, як свої, звичні, однак частина зберігала стилістичну маркованість іншомовного слова.

\section{Література}

1. Афанасьев А. Н. Поэтические воззрения славян на природу. Опыт сравнительного изучения славянских преданий и верований в связи с мифическими сказаниями других родственных народов / А. Н. Афанасьев : у 3-х т. - М. : Совр. писатель, 1995 . - Т. 1.- 1995. - 416 с. ; Т. 2. - 1995. - 400 с. ; Т. $3 .-$ 1995. $-416 \mathrm{c}$.

2. Бодянский И. О народной поэзии славянских племен / И. Бодянский. - М. : [б. и.], 1837. - 152 с.

3. Булаховський Л. А. Питання походження української мови / Л. А. Булаховський // Булаховський Л. А. Вибрані праці : у 5-и т. - Т. 2. - К. : Наук. думка, 1979. - С. 9 - 216.

4. Бурячок А. А. Назви спорідненості і свояцтва в українській мові / А. А. Бурячок. - К. : Вид-во АН УРСР, 1961. - $148 \mathrm{c}$.

5. Буслаев Ф. И. О преподавании отечественного языка / Ф. И. Буслаев. - Л. : Гос. уч.-пед. изд-во Наркомпроса РСФСР, Ленинград. отд-ние, 1941. - 643 с.

6. Веселовский А. Н. Историческая поэтика / А. Н. Веселовский [ред., вступ. ст. и примеч. В. М. Жирмунский]. - [2-е изд., испр.]. - М. : УРСС, 2004. - 648 с.

7. Карпова В. Л. Проблеми вивчення історії словникового складу мови / В. Л. Карпова // Історія української мови. Лексика і фразеологія / [Винник В. О., Горобець В. Й., Карпова В. Л. та ін.; Русаніський В. М. (відп. ред.)]. - К. : Наук. думка, 1983. - С. 5-14.

8. Козлова Р. Б. Заимствованная лексика в языке русского фольклора : автореф. дис. на соискание науч. степени канд. филол. наук : спец. 10.01.01 «Рус. язык» / Р. Б. Козлова. - Казань : [б. и.], 1974. - 16 с.

9. Павленко Л. Лексичні полонізми ХІУ-ХУ ст. у сфері номінації осіб / Лариса Павленко // Проблеми славістики : зб. наук. праць. - Луцьк, 1996. - Вип. 2. - С. 10-14.

10. Павленко Л. До джерел словесних скарбів / Лариса Павленко. - К. : Вежа, 1997. - 191 с.

11. Потебня А. А. О некоторых символах в славянской народной поэзии / А. А. Потебня. - [2-е изд.]. - Харьков : [б. и.], 1914. - 243 с.

12. Русанівський В. М. Семантичні процеси в розвитку української лексики / В. М. Русанівський // Історія української мови: Лексика і фразеологія / [відп. ред. В. М. Русанівський]. - К. : Наук. думка, 1983. - C. 660-715.

13. Скляренко В. Г. Щоб наш коровай ясен був / В. Г. Скляренко // Культура слова. - 2000. Вип. 53/54. - С. 109-114.

14. Скляренко В. Г. Етимологічні розвідки. 5. Лад, лада, Лада, лагода / В. Г. Скляренко // Мовознавство. - 1996. - № 6. - С. 12-18.

15. Сологуб Н. Що таке обрус? / Надія Сологуб // Культура слова. - 2000. - Вип. 53/54. - С. 114-116.

16. Халимоненко Г. М. Лексика дум та історичних пісень (коментар тюрколога) / Г. М. Халимоненко // Укр. мова і літ. в школі. -1977. - №. 9. - С. 21-29. 
17. Bartmiński J. O języku folkloru / Jerzy Bartmiński. - Wrocław; Warszawa; Kraków; Gdańsk : Wydawnictwo Polskej Akademii Nauk, 1973. - 286 s.

\section{Умовні скорочення джерел}

АМ - Народные южнорусские песни : издание Амвросия Метлинского / Амвросий Метлинский. - К. : [б. и.], 1854. -472 с.

БГ - Гринченко Б. Д. Этнографические материалы, собранные в Черниговской и соседних с ней губерниях... Б. Д. Гринченко / Б. Д. Грінченко. - Чернигов : [б. и.], 1895 - 1899. - Т. 2. - 398 с.; у тексті арабськими цифрами подано том і сторінку.

ВП - Весільні пісні / [упоряд. та авт. вступ. ст. М. М. Шубравська]. - К. : Дніпро, 1988. - 475 с.

ВШ - Шухевич В. Гуцульщина / Володимир Шухевич. - [2-ге вид.] : у 5-и ч. - Верховина : Гуцульщина, 1999. - Ч. 4. - 1999. - 301 с.

ГВ - Ващенко Г. Виховний ідеал : підруч. для педагогів, молоді і батьків / Г. Ващенко. - Т. І. Полтава : Полтав. вісн., 1994. - 192 с.

ДЯ - Українські народні пісні, наспівані Д. Яворницьким. Пісні та думи з архіву вченого / [упоряд., авт. вст. ст., приміт. та комент. М. М. Олійник-Шубравська]. - К. : Муз.Україна, 1990. - 453 с.

33 - Закувало зозуленька : Антологія української народної творчості. Пісні, прислів'я, загадки, скоромовки / [упоряд., авт. передм. та приміт. Н. С. Шумада]. - К. : Дніпро, 1987. - 392 с. ; іл.

IM - Народні пісні в записах Івана Манжури / [упоряд., авт. вст. ст. та приміт. Л. С. Каширіна]. - К. : Дніпро, 1974. - 351 с.

КОП - Календарно-обрядові пісні / [упоряд., авт. вст. ст. та приміт. О. Ю. Чебанюк]. - К. : Дніпро, 1987. -392 с. ; іл.

Л - Записи автора 1998-2002 рр. від Т. М. Данилюк, 1932 р. н., жительки м. Луцька Волинської обл. (арх. автора).

ЛУ - Леся Українка. Зібрання творів : у 12 т. / Леся Українка. - К. : Наук. думка, 1977. - Т. 9. Записи народної творчості. Пісні, записані з голосу Лесі Українки. - 431с.

М - Український православний молитовник. - Козів : Козів. район. друк., 1999. - 90 [3] с.

MB - Фольклорні записи Марка Вовчка та Опанаса Марковича / [упоряд., авт. передм. і приміт. О. I. Дей]. - К. : Наук. думка, 1983. - 528 с.

МГ - Народні пісні в записах Миколи Гоголя / [упоряд., авт. післямови та приміт. О. І. Дей]. - К. : Дніпро, 1985. - 202 с.

МК - Костомаров М. І. Слов’янська міфологія : вибр. праці з фольклорист. та літ-ва / М. І. Костомаров. - К. : Либідь, 1994. - 382 с.

ММ - Українські народні пісні, видані М. Максимовичем (Фотокопія 3 вид. 1827 р.) / Михайло Максимович / підгот. вид. П. М. Попова. - К. : Вид-во АН УРСР, 1962. - 343 с.

Н - Записи автора 1996-1999 рр. від Т. М. Ковальчук, 1909 р. н., с. Новосілки Млинівського р-ну Рівненської обл. (арх. автора).

СБГ - Словарь української мови / [зібр. ред. журн. «Кіевская Старина», упоряд. 3 дод. власного матеріалу Борис Грінченко] : в 4 т. - К., 1907-1909. - Т. 1. - 1996. - 494 с. ; Т. 4. - 1996. - 562 с [3 с.]; у тексті арабськими цифрами подано том і сторінку.

СП - Співаюче Підляшшя: Українські народні пісні Північного Підляшшя у записах Оксани Савчук. - Більськ : Союз українців Підляшшя, 2006. - 210 с.

СІС - Словник іншомовних слів / ред. О. С. Мельничук. - [2-е вид., випр. і доп.]. - К: Головна редакція УРЕ, 1985. - 966 с.

ПД - Поліська дома : Фольклорно-діалектологічний збірник / упоряд. В. Давидюк й Г. Аркушин. Вип. 3 / [зібр., упоряд., комент. В. Давидюк]. - Луцьк : Твердиня, 2008. - 404 с.; у тексті арабськими цифрами подано випуск і сторінку.

ПК - Пісні кохання / [упоряд., авт. вст. ст. та приміт. О. І. Дей. - К. : Дніпро, 1986. - 366 с. ; іл.

ПЧ - Труды этнографическо-статистической экспедиции в Западно-Русский край : Материалы и исследования, собранные П. П. Чубинским / П. П. Чубинський. - СПб. : [б. и.], 1872 - 1878. - Т. 3. - 1872. - 523 с.; Т. 5. - 1874. - 1209 с.; у тексті арабськими цифрами подано том і сторінку.

ФК - Музичний фольклор з Полісся у записах Ф. Колесси та К. Мошинського. - К. : Муз. Україна, 1995. - 432 с.; нот.

Стаття надійшла до редакції 10.11.2011 р. 